\title{
Mainstreaming af kønsforskning
}

\section{Mainstreaming inden for naturvidenskab - også et spørgsmål om fag}

Af Inge Henningsen

$\mathrm{E}$ n succesfuld gennemførelse af den danske regerings mainstreamingstrategi vil kunne få stor positiv betydning for naturvidenskaben i Danmark. ${ }^{1}$

Sammen med Teknik er $\mathrm{Na}$ turvidenskab det hovedområde, hvor der er færrest kvinder (Ståhle 1999, 154), og et af dem hvor udviklingen hen mod en mere ligelig kønsfordeling går langsomst. ${ }^{2}$

I en tid hvor der er stigende bekymring for, at en svigtende tilgang til naturvidenskab vil medføre en kvalitetsmæssig svækkelse af forskningen, er det vigtigt at den naturvidenskabelige forskning tager alle nødvendige skridt til at rekruttere de bedste forskertalenter. I denne sammenhæng er det imidlertid af betydning at mærke sig, at når det gælder uddannelse og forskning, så prioriterer kvinder og mænd ikke bare forskelligt mellem hovedområder, men de vælger også forskelligt inden for de naturvidenskabelige fag. ${ }^{3}$

Mainstreaming er således også et spørgsmål om faglige prioriteringer.

I forskningssystemet er tildeling af stillinger og andre ressourcer i høj grad bestemt af det system af videnskabelig betydningsfuldhed, der er en vigtig del af den "tavse viden", som skaber de faglige værdier og holdninger hos de fleste videnskabsmænd. Ser man på kvindernes fagvalg inden for naturvidenskab har det imidlertid en tendens til at gå på tværs af de videnskabsinterne opfattelser af prestige, idet kvinder i højere grad end mænd vælger fag, der er relationelle, komplekse og retter sig mod undersøgelse af organiske sammenhænge (Henningsen 1993, 1998). Dette er fag der placerer sig lavt i et naturvidenskabeligt betydningshierarki, der stadig reelt er præget af positivisternes reduktionistiske skemaer, hvor matematik og fysik er idealer som alle andre videnskaber skal tilstræbe at nærme sig. Placeringen i det videnskabsinterne hierarki har ikke nogen sammenhæng med hvor intellektuelt krævende fagene er eller med deres aktuelle samfundsmæssige betydning. Hierarkiet er dog ikke bare en videnskabsintern konstruktion, men har nogle meget materielle konsekvenser, når det gælder tilgang til stillinger og ressourcer, der i dag fortrinsvis er placeret i fag, hvor der er mange mænd. Ståhle $(1997,1999)$ har fx. vist, at halvdelen af stillingerne ved de danske universiteter slås op i områder, hvor der ikke er kvalificerede kvindelige ansøgere. Sammenfaldet mellem områder med høj videnskabsintern prestige og områder, der prioriteres af mænd, er således en væsentlig faktor $\mathrm{i}$ kvinders fortsatte underrepræsentation i forskningsverdenen. ${ }^{4}$

Når de traditionelle prioriteringer således giver de fleste ressourcer til de traditionelle (mande)fag, sker det ud fra en helt forståelige tendens til, at 
de i systemet værende forskere synes at deres egne fagområder skal opprioriteres. Men denne indbyggede konservatisme $\mathrm{i}$ det universitære system accepteres eller ligefrem tilskyndes langt hen ad vejen af det politiske system. Fx hedder det i Den nationale forskningsstrategi $(1997,9)$ :

"Den nationale strategi er formuleret i en vanskelig balance

\section{Tilhører ved Kønsforskningsfestivalen}

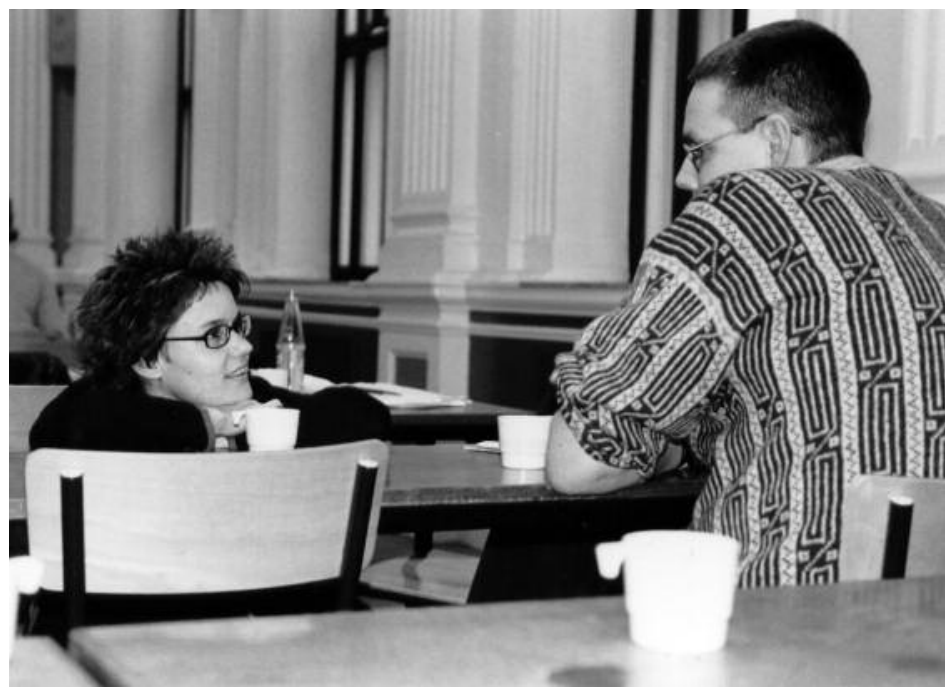
mod flere kvinder i naturvidenskaben er, at de traditionelle forskningsprioriteringer overlever. ${ }^{5}$ Lad mig imidlertid fjerne alle kønsovertoner, når jeg eksemplificerer, hvordan det traditionelle system fungerer, idet jeg sammenligner antallet af ph.d. stillinger på et gammelt og et nyt mandefag: på henholdsvis fysik og datalogi.

På Københavns Universitet ki. Den vigtigste barriere i dag

uddanner de to fag omtrent lige mange kandidater, men ser man på antallet af ph.d.-studerende så er der syv gange så mange ph.d.-studerende i fysik (83) som i datalogi (12) (Forskerakademiet 1999, 24). Er dette den prioritering af forskningsindsatsen, som vi har brug for i Danmark, i betragtning af den voldsomme udvikling og den stadigt stigende betydning af IT? Tager man mit eget område: de matematiske fag (matematik, statistik, finansiering, forsikringsmatematik og økonometri), så er der på fakultetet til sammen ni ph.d.-studerende (ibid.). Til trods for den samfundsmæssige betydning af en dybtgående forståelse af udviklingen på de internationale finansielle markeder, hvor den tilbagevendende uro i dag er en af de største trusler mod stabiliteten i verdenssamfundet. Jeg har ikke

Fra udstillingen 'Konsforskningens historie i 30 àr', Det Kongelige Bibliotek

mellem på den ene side det politiske systems krav om prioritering og på den anden side forskningsverdenens tradition for selvforvaltning, herunder frihed til selv at vælge indhold og mål”.

Den "nye" diskurs om videnskabelig kvalitet passer ligeledes som fod i hose til en forskningsprioritering med udgangspunkt i et traditionelt forstået videnskabernes hierar-

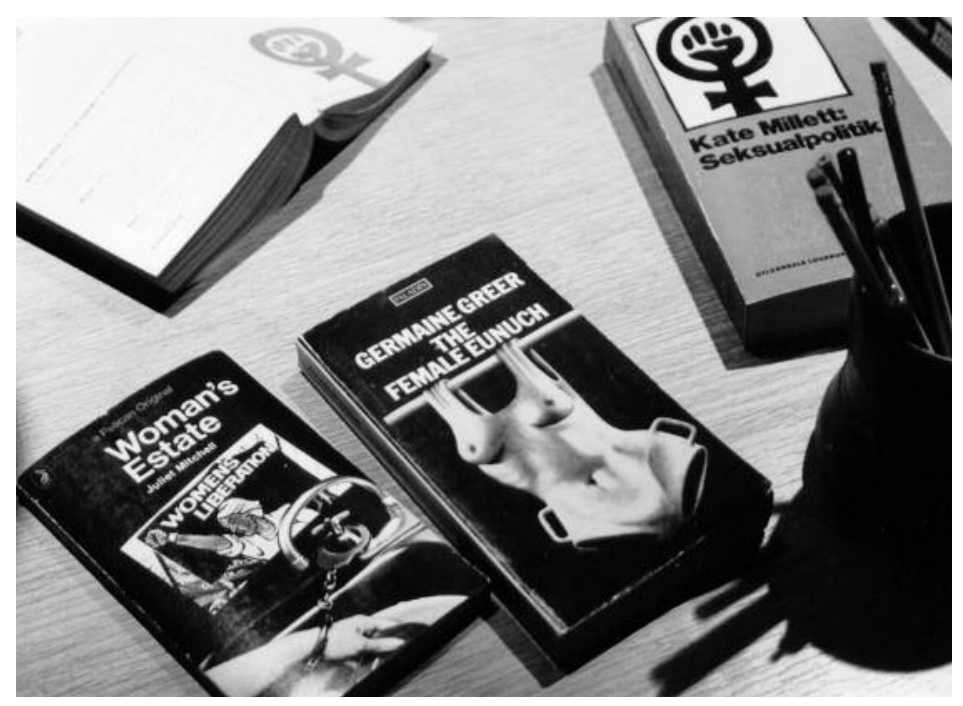


mødt nogen, der vil forsvare denne prioritering af forskningsindsatsen 6 , men heller ikke nogen der vil tage ansvar for den. Den er i høj grad et resultat af den ekstreme decentralisering, der kendetegner fx forskeruddannelsesområdet og som fører til nogle mærkværdige misforhold.

En vigtig barriere mod mainstreaming på forskningsområdet er den manglende erkendelse af, at dagens fordeling af forskningsressourcer ikke primært er bestemt hverken af forskningens kvalitet eller af samfundets behov, men først og fremmest afspejler eksisterende magtforhold, der søges legitimeret gennem en diskurs om kvalitet og samfundsnytte. Denne diskurs bliver sjældent seriøst udfordret i forskningsdiskussionerne - heller ikke af kvinder. Det er kun kvindernes faktiske prioriteringer i forskningen som går på tværs. $\mathrm{Og}$ mainstreaming: "at tænke køn ind på alle niveauer” er en højst forstyrrende faktor i et forskningssystem, som er vant til retfærdiggøre sine dispositioner i forhold til andre parametre.

Hvis køn skal indtænkes på alle niveauer, kunne man som en start forlange, at alle forsknings- og udviklingsplaner fra råd, ministerier og institutioner - indeholdt en vurdering af planernes forventede virkninger på områdets kønssammensætning. I dag forlanger fx. DANIDA sådanne "gender impact assessments" fra alle der søger bistandsbevillinger. Undersøgelser viser, at forskningsområderne er meget stabile (Henningsen 1998) når det drejer sig om hvilke områ- der der har mange og hvilke der har få kvinder. Ydermere kan aktørerne til enhver tid skaffe sig et næsten fuldstændigt overblik over "markedet" - større er forskersamfundene ikke. Det vil derfor være enkelt at vurdere de kønsmæssige konsekvenser af konkurrerende prioriteringer og planer.

Det er ikke mit ærinde her at argumentere for, at forskernes køn i sig selv skal være en væsentlig parameter, når forskningen prioriteres. Men jeg mener, at kvinders samfundsmæssige prioriteringer skal være en væsentlig faktor, og jeg ser aktuelt disse prioriteringer afspejlet i de kvindelige forskeres valg. Det er ydermere min helt konkrete opfattelse, at hvis man på naturvidenskab og på de naturvidenskabelige grænseområder i dag - overordnet og på de enkelte fag - opprioriterede nogle af de fagområder, hvor der var relativt mange kvinder, så ville dansk naturvidenskab få en stærkere og mere relevant forskningsprofil.

\section{Noter}

1. Se The ETAN report 2000.

Denne rapport og det EU-seminar, hvor den bliver fremlagt vil blive omtalt i næste nummer af Kvinder, Køn \& Forskning.

2. På Københavns Universitets naturvidenskabelige fakultet er kvindeandelen blandt de faste videnskabelige medarbejdere i dag den samme som den var for 30 år siden (Ståhle 1999, 165-167. Lektionskatalog, KU, 1970).

3. NIFU 1998, The ETAN report 2000 .

4. Det at kvinderne placerer sig i visse naturvidenskabelige fag er ikke forankret i kvinders natur, men skal snarere forstås som et resultat af individuelle kvinders bestræbelser på at få personlige erfaringer og projekter til at passe med de muligheder uddannelses- og forskningssystemet giver. Se fx diskussion i Annfelt 1999.

5. Disse konstateringer skal ikke tolkes som et forsvar for det eksisterende "cigarkassesystem" i forskningsbevillingerne. Dette system tjener samlet set ikke til at skabe mangfoldighed. Det medfører tværtimod en ensretning og en traditionalisering af forskningen. For det første er det i høj grad - om ikke de samme personer - så den samme faglighed, der styrer cigarkasserne og dermed bevillingerne. Samtidig er der en klar tendens til, at når der kun uddeles få stillinger eller mio. ad gangen er det de traditionelle fag og fagområder, der bliver tilgodeset hver gang. Dette synspunkt udtrykkes $\mathrm{fx}$. af direktør i Forskningsstyrelsen Jens Morten Hansen “... vi har for mange små cigarkasser ... hvor man kan gå for vidt med at detaljere opslaget, således at kun bestemte forskere i realiteten kan komme i betragtning. Denne 'øremærkning' kan foregå på mange - bevidste eller ubevidste måder ..." (Forskerforum 132, 4). Man må imidlertid anerkende, at kønsforskningen stort set er muliggjort ved udefra kommende initiativer.

6. Den samlede fordeling forklares som oftest med, at de udefra kommende bevillinger går til bestemte fag. Det er imidlertid en politisk beslutning, at ph.d.-graderne i Danmark i så høj grad skal være eksternt financierede. Norge har fx. et helt andet system. 


\section{LITTERATUR:}

- Annfelt, Trine (1999): Kjønn $i$ utdanning, Senter for Kvinneforskning, NTNU, Trondheim. . EU (2000): The ETAN report: Science Policies in the European Union: promoting excellence through mainstreaming gender equality, Bruxelles.

- Forskerforum (2000): Inhabile forskere? p. 132, København. . Forskningsministeriet (1997): Den nationale forskningsstrategi. København.

- Henningsen, Inge (1993): Observations and Conjectures on Women and the Sciences, Working Paper 3:1993, Gender-NatureCulture, Odense University. - Henningsen, Inge (1998): Lagevidenskab og køn. En analyse af det legevidenskabelige omraide pa Københavns Universitet med henblik på en kortlagning af kvindernes placering blandt de videnskabeligt ansatte. Arbejdspapir nr. 2, Køn i den akademiske organisation. København.

- NIFU (1998): Rekruttering til matematikk, naturvidenskap og teknologi innenfor bøyere utdanning $i$ de nordiske land, Tema Nord 1998: 505, Oslo. - Ståhle, Bertel (1997): Kvinder og mond $i$ dansk universitetsforskning. Undervisningsministeriet. København.

- Ståhle, Bertel (1999): Alder, køn og rekruttering $i$ dansk universitetsforskning. Undervisningsministeriet. København.

Inge Henningsen, cand. stat, lektor, afdeling for statistik og operationsanalyse, Københavns Universitet.

\section{Mainstreaming af køn i forskningen med ud- gangspunkt i samfunds- videnskaberne}

Af Karen Sjorup

\section{Mainstreaming som inter-} national ligestillingsstrategi Mainstreaming har siden Beijing 1995 internationalt været kodeordet for arbejdet med ligestilling. Det gælder såvel i FN-organisationerne, EU og Europarådet. I EU-kommissionens fjerde handlingsplan for ligestilling indgår mainstreaming således som en overordnet ramme, således som det også er skrevet ind i Amsterdamtraktaten. Man taler om en tostrenget strategi, der skulle sikre, at de hidtidige ligestillingstiltag ikke blot forlades. Strategien består på den ene side i mainstreaming bl.a. i betydningen 'gender impact studies' og på den anden side i ligestillingsinitiativer, 'positive action', altså særlige programmer rettet mod kvinder.

For mit vedkommende, som dansk national ekspert gennem tre år på området Gender and Employment i EU-kommissionen, har dette betydet, at jeg hvert år har skullet vurdere gender impact af den danske nationale beskæftigelsesstrategi (NAP). Dette samtidig med at det kontor i arbejdsministeriet, der står for disse nationale beskæftigelsesplaner og deres årlige revision, aldrig har lagt nogen kønsdimension ind i arbejdet. Det har man bl.a. gjort ud fra antagelsen om, at kvinder ikke havde nogen særlige arbejdsløshedsproblemer, men altså direkte i modstrid med den overordnede EU-politik, som den danske regering har tiltrådt. Deri står den danske regering imidlertid ikke alene, for til trods for at mainstreamingstrategien også på beskæftigelsesområdet er tiltrådt af alle medlemslande, er det de færreste som har taget notits af dette. Man kan således tale om, at mainstreamingstrategien fortrinsvis fungerer på det deklamatoriske niveau, mens der tilsyneladende sker relativt lidt på det praktiske plan.

I 1999 deltog jeg med en national rapport i en fælles EU-rapport om mainstreaming på arbejdsmarkedsområdet. Det samlede resultatet af dette arbejde er stadig ikke fremkommet, og mit indtryk fra de øvrige eksperter var for det første at selve ordet mainstreaming blokerer, fordi det ikke betyder noget på de nationale sprog udover engelsk og for det andet at de tiltag, som bliver præsenteret som mainstreamingstiltag, til forveksling ligner det vi tidligere benævnede ligestillingstiltag. Men ord, begreber og signaler forandrer sig og sander til, så det kan jo være at mainstreaming forløser et engagement og udvikling af nye og mere omfattende metoder, der virker på længere sigt, som jeg blot har svært ved at få øje på.

Netop nu forhandler Udenrigsministeriets eksperter opfølgningen på Beijing platformen, Beijing +5 , og så vidt jeg forstår arbejder den danske delegation som indgår i EU's fælles delegation på at opretholde mainstreamingstrategien. 


\section{Mainstreaming af forskningen}

Mainstreaming af køn i forskningen må efter min opfattelse først og fremmest forstås som at kønnet skal mainstreames ind i al forskning - især den, som ikke forstår sig selv som kønsforskning. For at blive i den internationale terminologi forudsætter mainstreamingstrategien, at forskningen generelt underkastets 'gender impact studies', at det skal vurderes,
Som Tereza Rees (Rees 1998) skriver, er

"det første stadie i mainstreamingen at anerkende, at det som bliver betragtet som normen ikke nødvendigvis er kønsneutralt. Essensen i mainstreaming tilgangen er at identificere de skjulte, oversete og ubemærkede måder, hvorpå systemer og strukturer indeholder en skævhed til fordel for mænd og derpå at genoprette

Tilhører ved Kønsforskningsfestivalen.

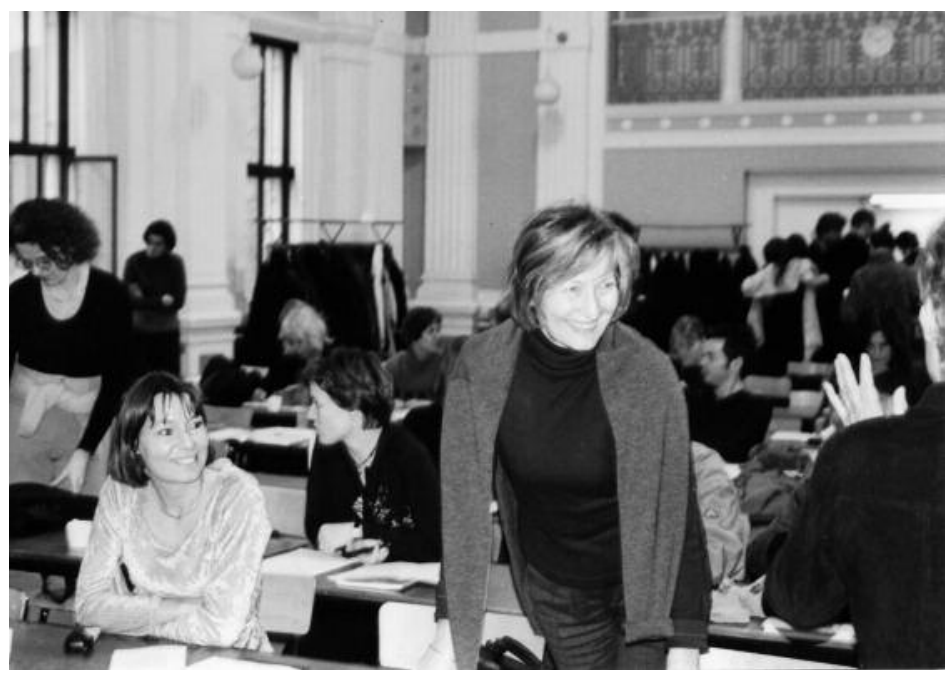

balancen. At se, hvordan tilsyneladende kønsneutrale praksisser som tilsyneladende tilbyder lige adgang for alle i realiteten fungerer som ekskluderende mekanismer i forhold til kvinder."

Dvs. at man forpligter forskningen på mainstreamingen. Dette implicere, at man dels må anerkende sin kønsskævhed og forpligte sig på at udvikle metoder til at genoprette eller oprette en balance.

\section{Hvordan skal}

mainstreaming af forskningen faktisk kunne realiseres?

Under alle omstændigheder dækker kønsskævheden over det faktum, at der udbydes flest forskningsressourcer der, hvor der er færrest kvinder, og derfor er det vanskeligt blot at fremsætte mainstreaming kravet adskilt fra en egentlig

Fra udstillingen 'Konsforskningens historie i 30 àr', Det Kongelige Bibliotek hvordan konkrete forskningsinitiativer bidrager til at opretholde en lige balance mellem mænd og kvinder. Dette er generelt et meget ambitiøst forehavende og det har da heller ikke hidtil været praktiseret. Derimod har Freja-programmet jo været en 'positive action' til fordel for kvinder, ligesom også SSF's aktuelle opslag af særlige post.doc.stipendier til kvinder er det.

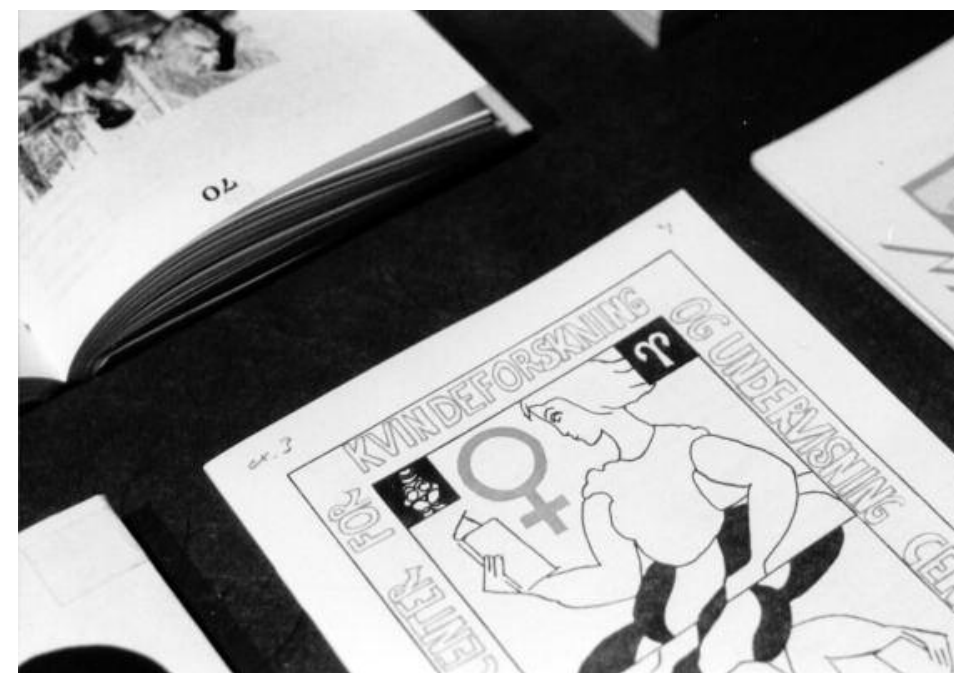


forskningsprioritering. Der er således netop udsendt oplæg fra EU ved Kommissær Philippe Buisquin til et 6. rammeprogram for forskningen. Den overordnede linie i papiret er, at man skal understøtte forskningen der, hvor den er værdifuld for den europæiske vækst dvs. især inden for de applicerede naturvidenskaber, hvilket endnu engang er de områder, hvor der er færrest kvindelige forskere. Der ofres en lille halv side ud af de 30 på at fremsætte ønsket om en større rolle for kvinder i forskningen, uden at dette dog ses i relation til den samlede aktionsplan.

Der henvises blot til det oplæg om mainstreaming i forskningen som netop er udsendt og til en aktionsplan, som skulle følge i kølvandet. Problemet er imidlertid, at alle andre sider i oplægget implicerer tiltag, som virker i modsat retning altså i retning af, at man prioriterer forskning på de områder, hvor der er færrest kvinder, idet man som overordnet mål har at fremme den økonomiske vækst i et samlet Europa og mener at dette skal gøres ved at prioritere bioteknologisk, teknisk og farmaceutisk forskning i samarbejde med de private virksomheder.

Det er således nødvendigt at man allerede i disse indledende trin til nye forskningssatsninger medtænker mainstreamingen aktivt, hvis den skal have nogen effekt. Tilsvarende skal der laves gender impact vurdering på alle programmer og tilsvarende på ansøgninger. Endelig skal der iværksættes nye programmer for at realisere en ba- lance mellem mandlige og kvindelige kandidaters muligheder for en forskningskarriere.

\section{Mainstreaming af kønsforskningen}

Skal man tænke den anden vej rundt, at det er kønsforskningen der skal mainstreames, må man vel sige, at det er den for længst blevet på det samfundsvidenskabelige område.

Kønsforskningen indgår her typisk i en række større projekter bl.a. magtudredningen og 'de menneskelige ressourcer i arbejdslivet' som mindre delperspektiver. Man kan således måske sige, at der sker en mainstreaming af kvindeforskningens teoretiske og metodiske landvindinger, eller måske modsat fungerer perspektivet blot som et empirisk korrektiv ind i en forskning, som hviler på et helt andet teoretisk fundament.

Der er således langt fra tale om, at dansk samfundsvidenskabelig kvindeforskning blot er et vedhæng til ligestillingspolitikken, sådan som det hævdes, at den er det i Norge og Sverige. Jeg vil snarere hævde, at der er opstået et meget stort tomrum af mangel på samfundsvidenskabelig kønsforskning, der måske kunne forhindre, at et ligestillingspolitisk udsagn kunne skydes i sænk af enkeltindividers personlige oplevelser af tingenes tilstand.

Vi mangler i Danmark således aktuel forskning på en række områder, som burde danne baggrund for og kvalificere ligestillingsdebatten. Der mangler bl.a. forskning om lønforskelle, ældre kvinders arbejdsmarkedsproblemer, enlige fo- rældres økonomiske vilkår og den voksende pornograficering af kvinders kroppe i medier og reklamer.

Det ville måske være en idé, at man som foreslået i Hilda Rømers debatoplæg iværksatte en koordinering af den allerede mainstreamede kønsforskning og dermed sikrede at der skete en synliggørelse og teoretisk bearbejdning og empirisk koordinering af disse områder.

Men det er jo tankevækkende, at mens forskningen på de fleste andre områder udparcelleres i stadig mindre specialområder, så har det ikke været legitimt eller økonomisk muligt at opretholde et center for samfundsvidenskabelig kvindeforskning. Kvindeforskningen skal mainstreames ind i en ikke-eksisterende mainstream.

Jeg har allerede i det indeværende korte år, dvs. i denne måned, været med til at indvie to nye centre på RUC nemlig et for turismeforskning og et for ungdomsforskning. Uanset begge er særdeles relevante og velbegrundede og i øvrigt heller ikke savner hverken offentlig eller privat finansiering, så undrer jeg mig stadig over, at det ikke er muligt at gøre det samme med kvindeforskningen.

\section{Flere kvinder i forskningen}

Den eneste årsag kan være, at universitetsforskningen og særlig dens rådgivende og bevilgende organer stadig, til trods for at over halvdelen af de studerende er kvinder, domineres af mænd. Det er også sådan, at den udvidelse af forskningskapaciteten på universiteterne i de senere år for- 
trinsvis er sket der, hvor der er færrest kvinder og i øvrigt også generelt færrest studerende.

Det kan man bl.a. se i Ståhlerapporten udtrykt $i$, at der er relativt få kvinder i den supplerende stillingsstruktur (forskningsprofessor, forskningslektor, forskningsadjunkt), som i øvrigt generelt er mest udbredt på områder med få kvinder.

Den supplerende stillingsstruktur har i de senere år fungeret som det væsentligste vækstlag i forskerrekrutteringen. Flere og flere forskningsårsværk kanaliseres over i disse stillinger, som typisk finansieres gennem eksterne midler og forskningsrådsmidler og samtidig fungerer som en alternativ og supplerende rekrutteringsvej til de ordinære stillinger. Men der er en tendens til at kvinder, som har gennemført ph.d., ikke forbliver i forskningssystemet. Især på det naturvidenskabelige område, hvor man ellers skulle forvente, at der var særlig stor efterspørgsel efter kvinderne, uddannes der mange kvindelige ph.d.-ere, som ikke siden forbliver i en forskerkarriere.

\section{Konklusion}

Jeg mener, som jeg har fremført mange gange før, at mainstreamingstrategien er en farlig vej med mange faldgruber og muligheder for, at det overordnede mål tabes af syne. Den forudsætter, at de politiske agenter for den har en meget overordnet gennemslagskraft, og sådan er det ikke i øjeblikket. Mainstreamingstrategien bliver, uanset det forekommer tautologisk, placeret ud på et sidespor som sær-strategi, der må forlade sig på en mainstream i forskningen, som den øvrige forskning for længst har forladt.

Forskningspolitik er generelt et stærkt politiseret felt, hvor stærke kræfter virker i retning af krav om en kommerciel udnyttelse af forskningsresultater (eller som det hedder i Danmarks forskningsråds nysudkomne årsrapport: "For at opretholde væksten i den private sektors forskning og dermed styrke Danmarks Internationale konkurrenceevne, må den offentlige forskning også vokse"), snarere end i retning af en understregning af behovet for styrkelse af forskningen på de områder, hvor der er mange studerende således at undervisningens forskningsbasering kan fastholdes.

Jeg mener, at mainstreamingstrategien, hvis den - som det ser ud til nu - fastholdes, må følges op af en meget mere grundlæggende diskussion af forskningsprioritering. Det er ikke kun hensynet til rekruttering og af kvindelige forskere på kvindelige forskere som taler for, at offentlige forskningskroner anvendes til at fastholde al universitetsundervisning som forskningsbaseret og derfor også prioriterer de områder, der i dag udpines. Det er heller ikke kun hensynet til rekruttering og fastholdelse af kvindelige forskere, der taler for, at offentlige forskningskroner anvendes på forskning $\mathrm{i}$ demokrati, kulturforskelle, sociale relationer, miljø og sundhed.
ANVENDT LITTERATUR:

- Tereza Rees (1998): Mainstreaming Equality in the European

Union. Routledge, London. - Towards a European Research Area. Communication from the Commission to the Council, the European Parliament, the Economic and Social Committee and the Committee of the Regions. Brussel 18. januar 2000. - Berthel Ståhle (1998): Kvinder og mand I dansk universitetsforskning I 1990'erne. Undervisningsministeriet.

- Danmarks Forskningsråds Årsrapport: Kortlagning af de offentlige forskningsmidler. December 1999.

\section{Karen Sjørup}

Prorektor og sociolog, lektor i kvindeforskning, Roskilde Universitets Center 


\section{Hvordan kan kvinde- og kønsforskningen navigere mellem magtens centre og periferiens monstre?}

\section{Af Nina Lykke}

M ainstreaming handler om at navigere mellem magtens centre og periferiens monstre, og det er svært. Hvordan undgås isolation på den ene side og assimilation og usynliggørelse på den anden? Det har i mange år været det store spørgsmål i debatten om institutionalisering af kvinde- og kønsforskningen. I dette debatoplæg vil jeg for det første ud fra mine personlige erfaringer understrege, at mainstreaming må tænkes kontekstuelt. Hvad der kan være en god mainstreamingstrategi i én kontekst, kan vise sig at være en blindgyde i en anden. For det andet vil jeg komme med et forslag, der måske kan bringe kvinde- og kønsforskningen ud af den institutionelle udsultningsproces, der er foregået op gennem 1990erne.

\section{Hvor gik kvinde- og køns-} forskerne hen, da de gik ud? Jeg er en af de oprindelige otte kvindeforskningslektorer, der blev ansat i Danmark som led i Folketingets Aktionsplan for kvindeforskning i 1986. I sommeren 1999 blev jeg forfremmet til professor i kønsforskning - ikke i Danmark, men i Sverige!

Når jeg sidder på flyvebåden over Øresund på vej til min nye arbejdsplads, Tema Genus, afdelingen for tværvidenskabelig kønsforskning og forskeruddannelse på Linköpings
Universitet i Sverige, og kaster blikket tilbage til Danmark, bliver jeg opfyldt af undren. Det undrer mig, at der er så enorm stor forskel på den opbakning, kvinde- og kønsforskningen i dag har i de to nabolande. Kvinde- og kønsforskningen har igennem 1990erne været behandlet som et perifert monster i Danmark. I Sverige derimod er den mægtig i vælten. Feminismen blomstrer derovre; de unge strømmer ind til kønsforskningen på universiteterne; og der er en helt anderledes opbakning ovenfra!

Lad mig nævne et par eksempler på det sidste:

1. Jeg har nu en stilling, der simpelt hen ikke findes magen til i Danmark. Jeg er nemlig professor i kønsforskning. Det kan man ikke blive i Danmark.

2. Jeg er sammen med to andre kønsforskningsprofessorer og to forskerassistenter ansat til at opbygge en hel ny afdeling for tværvidenskabelig kønsforskning, Tema Genus, der - når den er fuldt udbygget - skal spænde over både humaniora, samfundsvidenskab og naturvidenskab. Foreløbig dækker vi områderne køn og kultur, samt køn og økonomi. En sådan afdeling virker som en fuldstændig utopisk tanke i Danmark.

3. Sammen med mine fire kolleger er jeg ansat til at udvikle en 5-årig forskeruddannelse i kønsforskning. En sådan satsning på en dybtgående uddannelse på kandidat- og ph.d.-niveau, der har kønsteori og feministisk teori som kerne, er ligeledes utænkelig i Danmark. Det ved jeg af erfaring. Bakket op af Odense Universi- tet har jeg nemlig kæmpet med det danske undervisningsministerium i næsten ti år for at få lov at lave en kandidatuddannelse i kønsforskning. Men svaret her i Danmark har været Nej, nej, nej og atter nej. I Sverige derimod blev Tema Genus, min nye arbejdsplads, og den 5-årige forskeruddannelse i kønsforskning, vi skal stå for, til på initiativ af en 7-parti-motion. Kvinder fra alle partier i den svenske rigsdag enedes om at promovere forslaget, som herefter blev vedtaget, og mit nye universitet sagde med begejstring Ja tak til at huse initiativet. Det sker inden for rammerne af Institutionen för Tema, den store, i Norden unikke institution for temaorienteret og tværvidenskabelig forskning, der er en del af Linköping Universitets Filosofiske Fakultet. Denne temainstitution med sine mange tværvidenskabelige afdelinger - for kønsforskning, for etnicitetsforskning, for forskning i teknik og social forandring, for kommunikationsforskning, for sundhedsforskning etc. - er et ideelt miljø for at udvikle tværvidenskabelig kønsforskning.

4. Som et fjerde eksempel på forskellen mellem Danmark og Sverige, hvad angår støtte til kønsforskning og ligestilling, kan jeg berette, at jeg forleden var til møde med min nye rektor. Hans ærinde var, at vi på Tema Genus skulle inddrages som eksperter i forhold til universitetets ligestillingsudvalg. Bl.a. var rektor meget interesseret $i$, at vi skulle øse af vores kønsforsknings-ekspertise i forhold til at sørge for, at kønsperspektiver bliver integreret i 


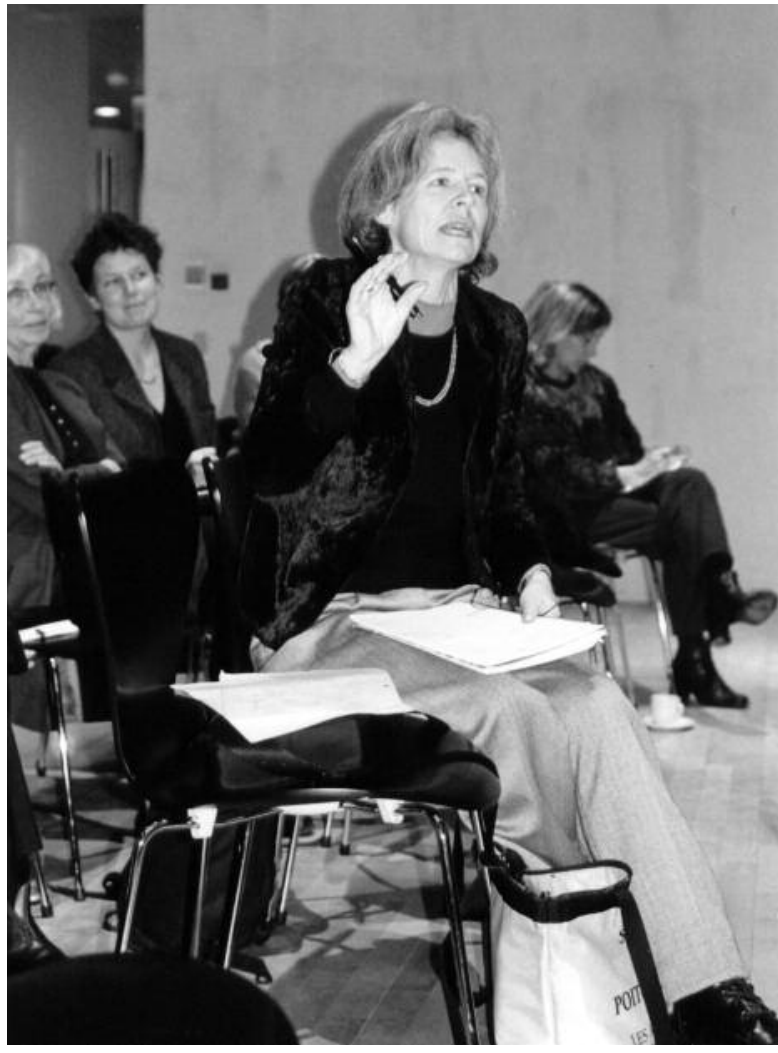

Nina Lykke turligvis ikke lade være at spørge: hvad i al verden er der galt i Danmark? Hvorfor er vi i Danmark - der med opbygningen af vores kvinde- og kønsforskningscentre i 1980erne og Folketingets Aktionsplan for kvindeforskning fra 1986 i den grad var i front med hensyn til institutionalisering og professionalisering på nordisk plan - i 1990erne sakket sådan bagud i forhold til f.eks. Sverige? Hvorfor er de kønsforskningskvalifikationer, som Folketinget med 1980ernes Aktionsplan investerede mange penge i, bl.a. til lektorater og forskningsstipendier, ikke særlig efterspurgte i Danmark i dag, hvorimod de er i høj kurs i Sverige?

\section{En invitation...}

Med denne personlige indledning vil jeg for det første slå et

undervisningens indhold og form på alle fakulteter og uddannelser inden udgangen af 2002. Til sammenligning kan jeg fortælle, at jeg i foråret 1999 - som medlem af fakultetsrådet på Syddansk Universitet - sammen med en gruppe studerende foreslog, at tilsvarende tanker skulle indgå i den udviklingskontrakt, som universitetet dengang forhandlede med ministeriet. Studenternes og mit fælles forslag blev fra de øvrige fakultetsrådsmedlemmers side mødt med larmende tavshed. En meget blød og tandløs formulering om numerisk ligestilling var alt, hvad vi trods ihærdige forsøg kunne få med i fakultetets forslag til

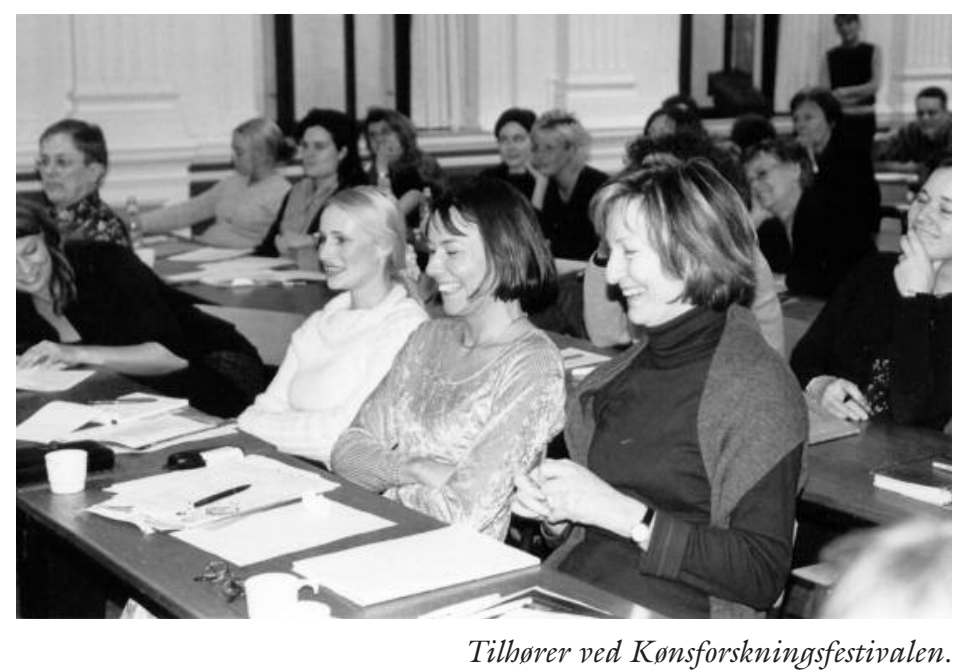

universitetets udviklingskontrakt.

På baggrund af mine nye svenske erfaringer kan jeg na- slag for, at ansvarlige politikere, universiteter og diverse bevilgende myndigheder faktisk 
tager ved lære af, hvad der sker i Sverige. Skal dansk kønsforskning gøre sig gældende i disse internationaliseringstider, må der ske noget! Det kræver ressourcer og synlighed at være med på et professionelt plan f.eks. $\mathrm{i}$ international sammenhæng - og bl.a. på både nordisk, europæisk og bredere internationalt plan sker der i disse år meget, som det er vigtigt at være med i. Men her har Danmark svært ved at være med. Bestemt ikke fordi dansk kvinde- og kønsforskning ikke er god. Den kan sagtens konkurrere internationalt. Men fordi vi, hvad institutionalisering og professionalisering af kvinde- og kønsforskning, stillinger til kvinde- og kønsforskning, muligheder for at uddanne sig inden for kvinde- og kønsforskning etc. angår, simpelthen sakker agterud. Den situation er dybt utilfredsstillende, og det vil jeg gerne opfordre de bevilgende myndigheder, herunder Folketinget, til at være med til at lave om på. Og for måske at give politikerne noget inspiration til, hvad der kan gøres, vil jeg som mit første konkrete forslag i dette debatoplxg - gerne invitere Folketingets Forskningsudvalg på besøg på mit nye universitet i Linköping. Her kan folketingsmedlemmerne se en stor, meget utraditionel og nyskabende institution for temaorienteret og tværvidenskabelig forskningsarbejde - og her kan de se, hvordan afdelinger for kønsforskning, etnicitetsforskning, børnekulturforskning, IT-forskning, sundhedsforskning og andre områder, som kræver et levende samspil mellem tvær-, trans- og enkeltvidenskabelighed, udgør et samarbejdende netværk. Og de kan se, hvordan kønsforskningen har en selvfølgelig og vigtig plads i netværket.

\section{Mainstreaming og kontekstualisering}

Det andet, jeg vil bruge mit Sveriges-eventyr til, er at understrege, at hele spørgsmålet om mainstreaming, om center og periferi, som denne konference drejer sig om, må ses $\mathrm{i}$ sin kontekst. I svensk sammenhæng er det mainstreaming at oprette en selvstændig afdeling for kønsforskning og en 5-årig forskeruddannelse i tværvidenskabelig og temaorienteret kønsforskning. Endvidere er det mainstreaming at bruge den unikke tværvidenskabelige forskningsekspertise, som oparbejdes ved et sådant initiativ, til bl.a. at gøre studiet af kønnets betydninger til en dimension af alle uddannelser på alle hovedområder. Her er mainstreaming både det, vi i gamle dage kaldte autonomi, og det, vi kaldte integration. Mainstreaming er ensbetydende med et både-og i stor skala - en dynamisk og forskningsforandrende kraft.

I en dødvande-situation som den nuværende danske kan mainstreaming derimod meget let komme til at betyde en blot og bar bekræftelse af den ligegyldighed over for kønnets betydninger i almindelighed og kønsforskningens udforskning af dem i særdeleshed, som hviler tungt over mainstream i dansk akademia. At mainstreame kønsforskning kan i den nuværende danske kontekst nemt komme til at betyde assimilation og tilpasning til en konservativ mainstream, der hævder, at køn er et ligegyldigt og for akademia uinteressant fænomen.

For at understrege, hvad jeg mener, når jeg siger, at mainstreamingstrategier på dansk grund i dag let kan løbe ind i store problemer, vil jeg minde om forskellige signifikante udtalelser fra agtværdige danske forskere, der efter min opfattelse langt hen er representative for det, der bliver tænkt om kvinde- og kønsforskning i dansk akademias mainstream og magtcentre.

Lise Hannestad og Birgit Nüchel Thomsen, der på baggrund af et mangeårigt arbejde i det danske forskningsrådssystem hævder at have god indsigt i dansk akademia, tog i en artikel i Politiken 6.2. sidste år ${ }^{1}$ skarpt afstand fra den mainstreaming af kvinde- og kønsforskning, som har fundet sted, i og med at feltet takket være bl.a. særinitiativerne i 1980erne faktisk er blevet en, om end perifer, så dog synligt institutionaliseret del af universiteterne. Hannestad og Nüchel Thomsen talte her med advarende stemme om, at "en særlig gruppe kvinder, specialiseret i en mere introvert kvindeforskning, har formået at skaffe sig særprivilegier og bedre vilkår end de kvinder, der arbejder på andre forskningsområder." En halvanden måneds tid tidligere havde to ligeså agtværdige repræsentanter for det danske forskersamfunds magtcentre, økonomiprofessor Birgit Grodal og filmvidenskabsprofessor Tor- 
ben Grodal udtalt sig på tilsvarende vis til Politiken. ${ }^{2}$ I

1970 erne og '80erne var det ifølge de to professorer i orden, at kønsforskningen fik lov at udvikle sig "med måde". "Men", fortsætter de advarende, "en yderligere opprioritering af forskningen i dag vil på uheldig vis skabe incitamenter til, at kvinder i særlig grad interesserer sig for egne forhold $\mathrm{i}$ særlige kønsghettoer og derved i mindre grad kvalificerer sig inden for almene, kønsneutrale emner." Eller med andre ord: Nu må der sættes en stopper for al den snak om kønnets betydning i forskningen, som kønsforskerne råber op om. Mainstreamingen er ved at gå alt for vidt!

Efter adskillige års erfaring med at sidde i styrende organer i akademia vil jeg understrege, at disse eksempler ikke er enestående. De udtrykker efter min opfattelse langt hen, hvad mainstream, magtens centre i dansk akademia tænker og mener om kvinde- og kønsforskningen! Det sætter selvsagt nogle barrierer for en mainstreamingstrategi! Og det så meget desto mere som det ser ud til, at disse magtcentre lever i bedste velgående, selv om vi måske befinder os i en postmoderne tid, hvor hybriderne yngler og såkaldt værdi- og personneutral forskning, som den de fire citerede forskere hylder, måske ikke er så tidssvarende mere. Det synes nemlig, som om der er mange af de forskere, som befolker magtens centre, der uden blusel tillader sig at ignorere, at postmodernister og kønsforskere har dekonstrueret det værdineutrale, positivitiske videnskabssubjekt og diskursivt lagt de magtcentre, det bebor, i ruiner. Ruiner eller ej, alle disse mange mainstream-forskere fortsætter ubekymret at hævde centrenes centrale og universelle betydning helt uden at ænse monstrøse og forstyrrende fænomener som køn, etnicitet, sexuel præference etc.

\section{Et forslag...}

Spørgsmålet er, hvad vi, kønsforskerne i periferien, skal gøre ved det? Ja, én ting, vi i hvert fald efter min mening ikke skal gøre, er at styrke de store monofaglige magtcentre ved at nedlægge de tværvidenskabelige centerdannelser, vi trods alt har opbygget i periferien. Selv om det er svært at fă øje på i det monomant monofaglige, danske forskningslandskab, mener jeg faktisk, at det, der foregår i periferien - foruden kønsforskning, også etnicitetsforskning, mandeforskning, lesbisk-bøsseforskning, forskning $\mathrm{i}$ "the inappropriate/d others"3 (dvs. de, der ikke passer ind i det gode selskab - i positivismens personneutrale akademia) - har fremtiden for sig. De forskere, der arbejder i denne periferi, har nemlig gjort sig klart, at en effektiv og tidssvarende forskning i dag bliver nødt til at kunne håndtere hybridfænomener, der ikke entydigt lader sig indskrive under én monofaglig synsvinkel.

Nogle af forskerne i periferien har desuden erkendt, at effektiv forskning i dag faktisk også bliver nødt til at optræde selvrefleksivt og stå ved, at dens vidensoparbejdning aldrig kan være værdi- og personneutral!
Men hvis vi på disse præmisser ikke blot kan opgive periferien til fordel for mainstream, er vi så fikseret i en håbløst marginal position? Eller med andre ord: Hvordan kan vi gøre periferien bredere og stærkere? Hvordan kan vi give den kraft til at underminere den monomant monofaglige mainstream? Måske kan vi tænke i nye tværvidenskabelige centerdannelser, der kan bidrage til destabiliseringen af monofaglighedens nuværende magtcentre.

I den sammenhæng kommer jeg til mit andet konkrete forslag, som jeg vil slutte dette debatoplæg af med at skitsere.

Mit forslag tager udgangspunkt $i$, at jeg kunne tænke mig et nærmere samarbejde hen over de grænser, der i dag går mellem kønsforskning, etnicitetsforskning, lesbisk-bøsseforskning m.v. Jeg tror, at tiden måske er inde til, at alle de, der forsker i "inappropriate/d otherness" begynder at arbejde nærmere sammen om fælles politiske fremstød.

Set fra mit udgangspunkt i kønsforskningen vil den første pointe i et sådant samarbejde være, at det er i overensstemmelse med stærke trends i den internationale kønsforskning. Den betoner jo netop, at det ikke kun handler om at se på kønnet, men på en hel række af samfundsmæssigt og kulturelt samvirkende akser af forskelle, der implicerer magtforhold og dominans - køn, etnicitet, sexuel præference, alder m.v. Et nærmere samarbejde mellem de, der forsker i "inappropriate/d otherness" vil efter min opfattelse for det andet 
være godt, fordi det vil betyde en generel styrkelse af periferien og dens forskningsforandrende virksomhed.

For at give vitaminer til igangsættelse af denne form for samarbejdsinitiativer kunne jeg tænke mig at opfordre Folketinget, Forskningsministeriet og forskningsrådene til i frllesskab at finde midler til at skabe et satsningsområde. Foreningen for Kvinde- \& Kønsforskning har tidligere stillet forslag til Forskningsministeriet om at finde midler til igangsættelse af større forskergrupper - såkaldte klynger med forskningsprofessorer, forskningslektorer/ -adjunkter, post-doc.stipendier og ph.d.-stipendier. Mit forslag er nu at udvide det oprindelige forslag på den måde, at der bli- ver tale om midler til en kombination af kønsforskning, etnicitetsforskning, lesbisk-bøsseforskning og andre former for forskning $i$ "inappropriate/d otherness". Der er lavet spredte indsatser på disse områder i 1990erne. Men hvorfor ikke indlede det nye årtusinde med en samlet stor satsning? Midlerne skal naturligvis udbydes efter FREJA-modellen dvs. i fri konkurrence, hvor de mange forslag nedefra får lov at udfolde sig. Det kunne gøre periferien større og bredere og give de nu udsultede lokale centerdannelser, periferiens "monstre", ny slagkraft!

\section{Noter}

1. Lise Hannestad og Birgit
Nüchel Thomsen: "Apartheidstatus for kvinder", Politiken 6.2.1999.

2. Birgit Grodal og Torben Grodal: "Kønspolitisk kulisse”, Politiken 16.12.1998.

3. Udtrykket er taget fra Donna Haraway "The promises of Monsters: A Regenerative Politics for Inappropriate/d Others", in: L. Grossberg, C. Nelson, P. Treichler: Cultural Studies, Routledge, London, New York 1992, pp. 295-338.

Nina Lykke, dr. phil. og professor ved Tema Genus, Linköpings Universitet, Sverige, og forshningsleder for projektet "Kyborger og cyberspace - mellem fortelling og socioteknisk virkelighed" under FREJA-programmet, tilknyttet Center for Kvinde- og Konsstudi- 